\title{
Hubungan Asupan Fe dan Vitamin A dengan Kejadian Anemia pada Ibu Hamil Trimester III di Puskesmas Air Dingin Kota Padang
}

Indah Lisfi ${ }^{1}$, Joserizal Serudji ${ }^{2}$, Husnil Kadri ${ }^{3}$

\begin{abstract}
Abstrak
Anemia adalah keadaan berkurangnya kadar hemoglobin dalam darah. Prevalensi anemia pada ibu hamil di Puskesmas Air Dingin Kota Padang mencapai 32,5\%. Faktor penyebab utama anemia ibu hamil pada umumnya adalah defisiensi zat besi. Anemia juga dapat disebabkan oleh defisiensi mikronutrien lain seperti vitamin A. Tujuan penelitian ini adalah menentukan hubungan asupan Fe dan vitamin A terhadap anemia pada ibu hamil trimester III di Puskesmas Air Dingin Padang. Desain penelitian ini adalah studi analitik dengan pendekatan cross-sectional. Pengambilan sampel dengan cara consecutive sampling dengan jumlah sampel 44. Data penelitian diperoleh melalui FFQ dan hemometer digital. Data dianalisis dengan chi-square strata bertingkat. Hasil penelitian ditemukan sebanyak $56,8 \%$ responden mengalami anemia, 59,1\% responden mempunyai asupan Fe dan vitamin A cukup. Hasil uji statistik chi-square menunjukkan nilai $\mathrm{p}=0,008$ untuk asupan $\mathrm{Fe}$ dan anemia, sedangkan berdasarkan asupan vitamin $\mathrm{A}$ didapatkan nilai $\mathrm{p} 1=0,399$ dan $\mathrm{p} 2=0,206$. Simpulan penelitian ini adalah adanya hubungan bermakna antara asupan Fe dengan anemia ibu hamil trimester III, tetapi tidak terdapat hubungan bermakna asupan vitamin A dengan anemia ibu hamil trimester III berdasarkan.
\end{abstract}

Kata kunci: anemia, asupan Fe, asupan vitamin A, ibu hamil trimester III

\begin{abstract}
Anemia is condition of reduced levels of hemoglobin in the blood. The prevalence of anemia in pregnant women in Air Dingin Health Center Padang reached 32.5 \%. The main causes of anemia in pregnant women generally is iron deficiency. In addition, anemia can also be caused by a deficiency of other micronutrients such as vitamin A. The objective of this study was to determine the correlation of Iron and vitamin A intake on anemia in the third trimester of pregnant women at Air Dingin Health Center Padang. Design of this study was analytic and cross-sectional study. Total samples were 44 pregnant women with consecutive sampling method. Data was obtained with FFQ and digital hemometer. The statistical analysis used was chi-square test with storied strata. The results showed $56.8 \%$ of the third trimester of pregnant women are anemia, 59,1\% have enough $\mathrm{Fe}$ and vitamin $A$ intake. The analysis showed $p$ value $=0,008$ for Fe intake and anemia, then based on vitamin $A$ intake $p$-value =0,399 and 0,206. The conclusion is a significant correlation between iron intake with anemia in the third trimester of pregnant women $(p<0.05)$ but there is no significant correlation between vitamin Fe intake with anemia in the third trimester of pregnant women based on vitamin A intake ( $p>0.05)$.
\end{abstract}

Keywords: anemia, iron intake, vitamin A intake, the third trimester of pregnant

Affiliasi penulis: 1. Prodi Profesi Dokter FK Unand (Fakultas Kedokteran Universitas Andalas Padang), 2. Bagian Obstetri dan Ginekologi FK Unand, 3. Bagian Biokimia FK Unand
Korespondensi: Indah Lisfi,indah_lisfi23@yahoo.com 


\section{PENDAHULUAN}

Ibu hamil merupakan salah satu kelompok yang rentan terhadap kekurangan gizi karena terjadi peningkatan kebutuhan untuk memenuhi gizi ibu beserta janin. ${ }^{1}$ Anemia merupakan masalah gizi yang terbesar dan tersulit diatasi di seluruh dunia. ${ }^{2}$ Prevalensi ibu hamil yang mengalami anemia di dunia mencapai $41,8 \%$, di negara berkembang mencapai $52 \%$ dan di Indonesia prevalensi anemia pada ibu hamil sekitar $44,23 \% .^{3}$ Kota Padang mempunyai $13,3 \%$ ibu hamil yang mengalami anemia dengan prevalensi tertinggi di Puskesmas Air Dingin yang mencapai $32,5 \%{ }^{4}$

Anemia yang terjadi pada sebagian ibu hamil disebabkan karena pada masa kehamilan terdapat peningkatan kebutuhan zat makanan dan perubahan dalam darah. Anemia akan memberikan pengaruh yang buruk bagi kesehatan ibu dan janin, yaitu keadaan ini akan meningkatkan morbiditas dan mortalitas ibu dan anak. ${ }^{5}$

Defisiensi zat gizi yang paling banyak terjadi pada ibu hamil yang dapat menyebabkan anemia adalah zat besi. Kebutuhan zat besi meningkat pada ibu hamil terutama pada trimester III. Hal ini menyebabkan ibu hamil pada trimester III lebih rentan mengalami defisiensi zat besi. ${ }^{5}$

Anemia tidak hanya disebabkan oleh defisiensi zat besi tetapi juga karena defisiensi mikronutrien seperti vitamin A. Defisiensi vitamin A menyebabkan anemia karena vitamin $A$ dapat mempengaruhi eritropoiesis. $^{6}$

Penelitian ini bertujuan untuk mengetahui hubungan asupan $\mathrm{Fe}$ dan vitamin A dengan kejadian anemia pada ibu hamil trimester III di Puskesmas Air Dingin Padang. Penelitian ini bermanfaat sebagai pengembangan ilmu dan salah satu upaya untuk menurunkan angka kejadian anemia pada ibu hamil sehingga mortalitas dan morbiditas ibu dan anak dapat dikurangi.

\section{METODE}

Desain penelitian ini adalah analitik dengan pendekatan cross-sectional study. Jumlah sampel pada penelitian ini adalah 44 orang ibu hamil trimester III yang memenuhi kriteria inklusi dan eksklusi. Kriteria inklusi antara lain; bertempat tinggal di wilayah kerja Puskesmas Air Dingin, ibu hamil trimester III, ibu hamil yang bersedia diperiksa $\mathrm{Hb}$ dan diwawancarai. Kriteria eksklusi adalah; ibu hamil yang mengalami infeksi, hemoglobinopati, aplasia sel darah dan mempunyai riwayat perdarahan. Pengambilan sampel dibagi setiap kelurahan dengan mengggunakan proportional random sampling. Pengambilan sampel di setiap kelurahan menggunakan consecutive sampling. Variabel dependen adalah kejadian anemia, sedangkan variabel independen adalah asupan Fe. Penelitian ini mempunyai variabel confounding yaitu asupan vitamin A. Data asupan Fe dan vitamin A diukur melalui wawancara dengan menggunakan formulir FFQ semi kuantitatif, sedangkan data kadar $\mathrm{Hb}$ diperoleh melalui pemeriksaan langsung dengan hemometer digital. Langkah pengolahan data adalah pemeriksaan kelengkapan dan kejelasan data, pemberian kode pada setiap data variabel, memasukkan data kedalam komputer, serta pemeriksaan kembali untuk memastikan bahwa data tersebut telah bersih dari kesalahan. Analisis data terdiri dari analisis univariat dan bivariat.

\section{HASIL}

Tabel 1. Distribusi frekuensi subjek penelitian berdasarkan umur

\begin{tabular}{ccc}
\hline Karakteristik (tahun) & $\mathbf{n}$ & $\%$ \\
\hline $21-25$ & 11 & 25 \\
$26-30$ & 18 & 40,9 \\
$31-35$ & 8 & 18,18 \\
$36-40$ & 5 & 11,36 \\
$41-45$ & 2 & 4,5 \\
\hline Total & 77 & 100 \\
\hline
\end{tabular}

Berdasarkan Tabel 1 dapat dilihat bahwa ibu hamil triemester III yang menjadi subjek penelitian terbanyak adalah kelompok umur 26-30 tahun.

Tabel 2. Distribusi frekuensi anemia berdasarkan kadar hemoglobin pada subjek penelitian

\begin{tabular}{ccc}
\hline Kadar Hb(g/d) & $\mathbf{n}$ & \% \\
\hline Anemia & 25 & 56,8 \\
Tidak Anemia & 19 & 43,2 \\
\hline Total & 44 & 100 \\
\hline
\end{tabular}


Berdasarkan Tabel 2 dapat dilihat bahwa lebih dari separuh ibu hamil trimester III mengalami anemia $(56,8 \%)$.

Tabel 3. Distribusi ferkuensi asupan Fe subjek penelitian berdasarkan kecukupan AKG

\begin{tabular}{ccc}
\hline Asupan Fe & $\mathbf{n}$ & $\%$ \\
\hline Cukup & 26 & 59,1 \\
Kurang & 18 & 40,9 \\
\hline Total & 44 & 100 \\
\hline
\end{tabular}

Tabel 3 memperlihatkan bahwa lebih dari separuh subjek penelitian mempunyai asupan $\mathrm{Fe}$ cukup $(59,1 \%)$.

Tabel 4. Distribusi frekuensi asupan vitamin A subjek penelitian berdasarkan kecukupan AKG

\begin{tabular}{ccc}
\hline Asupan Vitamin A & $\mathbf{n}$ & \% \\
\hline Cukup & 26 & 59,1 \\
Kurang & 18 & 40,9 \\
\hline Total & 44 & 100
\end{tabular}

Pada Tabel 4 dapat dilihat bahwa lebih dari separuh subjek penelitian mempunyai asupan vitamin A cukup $(59,1 \%)$.

Tabel 5. Hubungan asupan $\mathrm{Fe}$ dengan kejadian anemia pada ibu hamil trimester III di wilayah kerja Puskesmas Air Dingin

\begin{tabular}{|c|c|c|c|c|c|c|}
\hline \multirow{3}{*}{$\begin{array}{c}\text { Asupan } \\
\mathrm{Fe}\end{array}$} & \multicolumn{4}{|c|}{ Anemia } & \multirow{3}{*}{ Nilai $p$} & \multirow{3}{*}{$\begin{array}{c}\text { OR } \\
(95 \% \mathrm{Cl})\end{array}$} \\
\hline & \multicolumn{2}{|c|}{ Ya } & \multicolumn{2}{|c|}{ Tidak } & & \\
\hline & $\mathrm{n}$ & $\%$ & $\mathrm{n}$ & $\%$ & & \\
\hline Cukup & 10 & 40 & 16 & 84,21 & \multirow{2}{*}{0,008} & \multirow{2}{*}{0,125} \\
\hline Kurang & 15 & 60 & 3 & 15,78 & & \\
\hline Total & 25 & 100 & 19 & 100 & & \\
\hline
\end{tabular}

Berdasarkan Tabel 5 dapat dilihat bahwa subjek penelitian yang anemia lebih banyak ditemukan pada responden dengan asupan Fe kurang (60\%) dibandingkan responden dengan asupan Fe cukup (40\%). Hasil uji statistik chi-square menunjukkan hubungan bermakna antara asupan $\mathrm{Fe}$ dengan kejadian anemia pada ibu hamil trimester III $(p<0,05)$.

Tabel 6. Hubungan Asupan Fe dengan kejadian anemia berdasarkan asupan vitamin A pada ibu hamil trimester III

\begin{tabular}{|c|c|c|c|c|c|c|c|}
\hline \multirow{3}{*}{ Asupan Fe } & \multirow{3}{*}{$\begin{array}{c}\text { Asupan } \\
\text { Vitamin A }\end{array}$} & \multicolumn{4}{|c|}{ Status Anemia } & \multirow{3}{*}{ p } & \multirow{3}{*}{$\begin{array}{c}\text { OR } \\
(95 \% \mathrm{Cl})\end{array}$} \\
\hline & & \multicolumn{2}{|c|}{ Anemia } & \multicolumn{2}{|c|}{ Tidak Anemia } & & \\
\hline & & $\mathrm{n}$ & $\%$ & $\mathbf{n}$ & $\%$ & & \\
\hline \multirow{2}{*}{ Cukup } & Cukup & 8 & 80 & 9 & 56,25 & \multirow{2}{*}{0,399} & \multirow{2}{*}{3,111} \\
\hline & Kurang & 2 & 20 & 7 & 43,75 & & \\
\hline & Total & 10 & 100 & 16 & 100 & & \\
\hline \multirow{2}{*}{ Kurang } & Cukup & 6 & 40 & 3 & 100 & \multirow{2}{*}{0,206} & \multirow{2}{*}{0,742} \\
\hline & Kurang & 9 & 60 & 0 & 0 & & \\
\hline & Total & 15 & 100 & 3 & 100 & & \\
\hline
\end{tabular}

Tabel 6 memperlhatkan bahwa responden yang mempunyai asupan Fe cukup dengan status anemia lebih banyak ditemukan pada responden dengan asupan vitamin A cukup (80\%). Sedangkan responden yang mempunyai asupan $\mathrm{Fe}$ kurang dengan status anemia lebih banyak ditemukan pada responden dengan asupan vitamin A kurang (60\%). Hasil uji statistic chi-square strata bertingkat menunjukkan tidak terdapat pengaruh asupan vitamin A terhadap asupan Fe cukup maupun kurang dengan kejadian anemia $(p>0,05)$.

\section{PEMBAHASAN}

Anemia adalah suatu keadaan dimana kadar hemoglobin dalam darah berada di bawahbatas normal. Pada ibu hamil trimester I dan III, batas kadar hemoglobin untuk anemia adalah $11 \mathrm{~g} / \mathrm{dl}$ sedangkan pada trimester II batas kadar hemoglobin adalah 10,5 g/dl. ${ }^{7}$ Pada penelitian ini didapatkan prevalensi anemia pada subjek penelitian sebesar $56,8 \%$ dengan rerata kadar $\mathrm{Hb}$ yaitu 10,9 g/dl. Penelitian ini menunjukkan hubungan bermakna antara asupan $\mathrm{Fe}$ dengan kejadian anemia pada ibu hamil trimester III. 
Ibu hamil trimester III yang anemia dengan asupan Fe kurang sebesar $60 \%$. Berdasarkan hal tersebut dapat disimpulkan bahwa pada umumnya anemia ibu hamil trimester III di wilayah kerja Puskesmas Air Dingin ini disebabkan oleh karena asupan Fe yang kurang. Asupan Fe yang kurang dapat disebabkan oleh kurangnya konsumsi makanan yang mengandung Fe sehingga tubuh ibu hamil tidak dapat mengimbangi kebutuhan $\mathrm{Fe}$ yang meningkat. Keadaan ini juga dapat disebabkan oleh kurangnya konsumsi makanan yang dapat meningkatkan absorbsi Fe seperti vitamin C. Vitamin C dapat meningkatkan absorbs besi di usus terutama besi non heme yang mempunyai tingkat absorbsi yang rendah. ${ }^{8}$ Terdapat beberapa mekanisme vitamin C dalam meningkatkan absorbs besi, yaitu dengan meningkatkan reduksi ferri menjadi ferro sehingga penyerapan lebih mudah dan menghambat efek dari zat tannin dan kalsium yang dapat menurunkan absorbsi besi di usus. ${ }^{9}$

Asupan Fe yang kurang pada ibu hamil juga disebabkan oleh kurangnya konsumsi Tablet Tambah Darah (TTD). TTD merupakan suplementasi gizi mikro khususnya zat besi dan folat yang diberikan kepada ibu hamil untuk mencegah kejadian anemia gizi besi selama kehamilan. ${ }^{10}$

Pada penelitian ini juga ditemukan bahwa $40 \%$ ibu hamil dengan asupan Fe yang cukup mengalami anemia. Hal ini dapat dipengaruhi oleh makanan atau minuman yang dapat menghambat absorbsi Fe seperti the dan kopi sehingga makanan yang dikonsumsi tidak dapat digunakan oleh tubuh secara optimal. ${ }^{8}$

Penelitian ini menunjukkan tidak terdapat hubungan antara asupan $\mathrm{Fe}$ dengan anemia berdasarkan asupan vitamin A. Sebanyak $43,75 \%$ ibu hamil trimester III yang tidak anemia dengan asupan Fe cukup mempunyai asupan vitamin A yang kurang. $\mathrm{Hal}$ ini dapat berkaitan dengan cadangan vitamin A di hati. Dalam keadaan normal, cadangan vitamin A dalam hati dapat bertahan hingga enam bulan. Hal tersebut dapat menjelaskan keadaan ibu hamil trimester III yang mempunyai asupan vitamin A kurang namun tidak anemia. Meskipun asupan kurang namun kebutuhan tubuh terhadap vitamin A tetap dapat tercukupi dengan cadangan vitamin $\mathrm{A}$ dalam tubuh. ${ }^{11}$
Penelitian ini tidak memperhitungkan semua faktor yang dapat mempengaruhi anemia pada ibu hamil trimester III seperti usia ibu, jumlah paritas, jarak kehamilan dan asupan vitamin C. Keterbatasan penelitian ini juga ditemukan pada instrumen yang digunakan untuk mengukur hb dan FFQ dimana menuntut responden untuk mengingat makanan sehari-hari.

\section{SIMPULAN}

Terdapat hubungan yang bermakna antara asupan Fe dengan anemia pada ibu hamil trimester III.

Tidak terdapat hubungan yang bermakna antara asupan $\mathrm{Fe}$ dengan anemia berdasarkan asupan vitamin A pada ibu hamil trimester III.

\section{DAFTAR PUSTAKA}

1. Ojofeitimi EO, Ogunjuyigbe PO, Sanusi. Poor dietary intake of energy and retinol among pregnant women: implications for pregnancy outcome in Southwest Nigeria. Pak J Nutr. 2008;7 (3):480-4.

2. Soekirman. Ilmu gizi dan aplikasinya untuk keluarga dan masyarakat. Jakarta: Direktorat Jenderal Pendidikan Tinggi Departemen Tinggi Departemen Pendidikan Nasional; 2000.

3. WHO. Prevalence of anaemia in pregnancy (diunduh Desember 2013). Tersedia dari: URL: HYPERLINK http://data.worldbank.org/indicator/ SH.PRG.ANEM

4. Dinas Kesehatan Kota Padang. Tabel cakupan bumil anemia tahun 2012. Padang: DKK; 2012.

5. Oliver E, Olufunto K. Management of anaemia in pregnancy. Dalam: Donald S, editor (penyunting). Anemia. Shanghai: Intechopen; 2012.hlm.233-45.

6. West KP, Gernand JA, Sommer A. Vitamin A in nutritional anemia. Dalam: Kraemer $K$, Zimmermann MB, editor (penyunting). Nutritional Anemia. Berlin: Sight and Life; 2006.hlm.133-48.

7. Cunningham FG, Gant FG, Leveno KJ. Obstetri Williams. Edisi ke-21. Suyono J, Harono A, penerjemah. Jakarta: EGC; 2005.

8. Centers for Disease Control and Prevention (CDC). Nutrition: Iron and iron deficiency (diunduh 29 Oktober 2014). Tersedia dari: URL: HYPERLINK 
http://www.cdc.gov/nutrition/everyone/basics/vitami ns/iron/.html

9. Cook JD, Reddy MB. Effect of ascorbic acid intake on nonheme-iron absorbtion from complete diet. Am J Clin Nutr. 2001;73(1):93-8.

10. Departemen Kesehatan RI. Program penanggulangan anemia gizi pada wanita usia subur. Direktorat Gizi Masyarakat. Jakarta:
Direktorat Jenderal Bina Kesehatan Masyarakat Depkes; 2003.

11. Kolsteren P, Rahman SR, Hilderband K, Diniz A. Treatment for iron deficiency anemia with combined supplementation of iron, vitamin A and zinc in women of Dinajpur. Bangladesh: Stockton press;1999.hlm.102-6. 